\title{
流れによる底泥の飛び出し率
}

\section{ESTIMATION OF RESUSPENSION RATE OF COHESIVE SEDIMENTS BY CURRENTS}

\author{
大坪国 順*・村 岡 浩 爾** \\ By Kuninori OTSUBO and Kohji MURAOKA
}

\begin{abstract}
The main purposes of this study are to investigate the influence of shear stress and sediment properties (sediment type, water content, viscosity and yield value) on the resuspension rates of a cohesive bed in streams, and to estimate theoretically the rate as a function of those parameters. Three clays and six muds with several different water contents were used as bed material. From the results obtained by dimensional analysis of experimental data, we concluded that the cohesive bed should be regarded as an aggregation of cohesive sediment for the resuspension phenomenon. A dimensionless resuspension rate function for cohesive sediment was deduced by establishing the equation of motion for a sliding sediment and considering the fluctuation of tractive force. This function showed good agreement with the experimental results.
\end{abstract}

Keywords : Cohesive sediments, Erosion rate, Mud, Resuspension rate

\section{1. 概 説}

底泥は一般に均一度の高い微細粒子群と有機物質の複 合体である．そのため流送に対する抵抗力としては粘着 力が重力より卓越すると考えられる. 底泥は通常 300〜 $1000 \%$ 程度の含水比で堆積しており, 含水比の大小に より流送抵抗力は著しく変化する．底泥の流送システム を理解するためには, (1) 底泥の初期移動機構（限界 掃流力および飛び出し率) の解明，（２）沈降・圧密機 構 (堆積状態) の解明, ( 3 ) 底泥床面上の流体力 (せ ん断応力）特性の解明，最後に，（4）浮上した底泥粒 子の水流中での挙動の解明が必要となる.これらの知見 を有機的に結びつけることにより現地での底泥の浮上量 (厚さ) の推定が可能となる. 前報1)での限界掃流力の 特性につづいて，ここでは飛び出し率を中心に底泥の初 期移動機構について考察する. 底泥の飛び出し率（浮上 率）に関する研究は少なく実験的にも個々の実験条件に ついて求められている程度である ${ }^{2) ~ 5)}$. 底泥の浮上現象 を研究するにあたっては, 床面での底泥を一相の連続体

* 正会員 工博 国立公害研究所研究員 水質土壤環境部 （干305 茨城県筑波郡谷田部町小野川 16-2）

** 正会員 工博 国立公害研究所部長 水質土㙵環境部 (同上)
として取り扱う方法と，底泥を何らかの大きさおよび形 状をもった粒状体の集合として取り扱う方法とがある. Partheniades は後者の立場に立ち, Einstein の方法 ${ }^{6} に$ 準拠してせん断応力の変動を考えて粒子の浮上率の評価 を試みた ${ }^{3)}$. 誘導した理論式が実験值によく合うとした が, 離脱・浮上時の条件やそれに要する時間を実験值に 合うように決めた点に問題が残る．細井は，底泥の飛び 出し量を連続体モデルで考えだ). Einstein $\& \mathrm{Li}^{8}{ }^{8}$ の粘 性底泥層の発達・崩壊モデルを, 水流層と泥層にそれぞ れ考えて, 泥層の浮上厚 $l$ なものを導いた. しかし， このモデルは密度流れ場での上層の流れによる下層の流 れの発達のモデルであって, 底泥の浮上率を評価するも のではないと考えられる.

流送実験で求めた飛び出し量を整理した結果, Table 1 に示した含水比条件の範囲内では，底泥の飛び出し現 象は粒状体として取り扱うのが適当であるという結論に 至った。この結論と底泥の飛び出しは瞬間に起こるので はなく時間のかかる現象であるという考察をもとに, 底 泥の飛び出し率の合理的な評価を試みた．粘度に起因す る流送抵抗力を考えて底泥粒子について滑動運動方程式 を立て,さらに流れの変動を考虑することによって底泥 の無次元飛び出し率の推定式を求めた。この推定式は底 泥の種類や含水比の影響を包括し, 実験結果とよい対応 
を示した。

\section{2. 流送実験の方法}

実験に用いた水路は，透明アクリル製の長方形断面 （幅 $15 \mathrm{~cm} \times$ 高さ $5 \mathrm{~cm}$ ) 管水路である. 全長は約 $10 \mathrm{~m}$, 長方形断面部の長さは $7 \mathrm{~m}$ で, その上流端から $4.5 \mathrm{~m}$ 下流に, 長さ $90 \mathrm{~cm} \times$ 幅 $5 \mathrm{~cm} \times$ 深さ $1.5 \mathrm{~cm}$ の移動床区 間が設けられている．断面平均濃度を測定するために, 移動床下流端から $50 \mathrm{~cm}$ 下流に流れを強制的に擾乱さ せる区間を設けた，所定の含水比の底泥を直接移動床に 敷き詰め微小流量で移動床面を冠水させた.その後ただ ちに流送実験を行った。 バルブ操作により流量を徐々に 増加させ，流量と濃度を連続的に自動記録した。非定常 流れによる付加せん断応力 $\Delta \tau$ の影響をなくするため, $\Delta \tau$ の増加の割合は $0.025\left(\mathrm{~N} / \mathrm{m}^{2}\right) / \mathrm{min} と し た{ }^{9)}$. 飛び 出し量はレーザー濃度計により計測した。水路を流下す る水は懸け流しとし，水温および泥温とも $20 \pm 5{ }^{\circ} \mathrm{C}$ の 条件で実験を行った。

飛び出し量を求めた底泥の種類と平均粒径 $d_{m}(\mu \mathrm{m})$ および含水比の条件を Table 1 に示す．表中○印で示さ れる含水比で 3 回ずつ流送実験を行った。含水比の範囲 は底泥によって異なるが，いずれも底泥の液性限界值よ り高い. 今回の実験条件では, 移動床に敷きつめた後 2 時間以内であれば，含水比は初期条件のまま鉛直方向に も一定と考えられる.

流量を漸次増加させる測定法を用いたため，30 秒間 もしくは 60 秒間の平均濃度と平均底面せん断応力との 関係を解析した．濃度計の出力の低下は流水中の底泥粒 子濃度の増加に対応し，また，飛び出した底泥粒子は移 動床部に再び停止・堆積することがないため, 濃度計の 出力低下量は移動床部での底泥の飛び出し量に直接結び ついている. 流送実験に関する詳しいことは文献 9), 10） を参照されたい。

\section{3. 実験結果の概要}

Fig. 1 の一連の図は, 飛び出し量 $P_{m}$ とせん断応力 $\tau$ の関係の一例である. 霞ケ浦泥 1 と印旛沼泥は第一底泥 グループに, ベントナイト $\left(\mathrm{Na}^{+}\right)$は第二底泥グループ に属する ${ }^{1}$ (底泥は, 沈降形態, 流動曲線および流送形

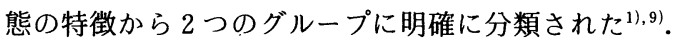
初期移動に深く関連すると考えられる流動曲線を例にと れば第一底泥グループでは降伏值 $\tau_{y 1}$ の存在と曲線の屈 曲が特徵であり, 第二底泥グループでは $\tau_{y 1}$ が存在せず 曲線が滑らか (ベキ乗則の成立) なことが特徴である). 含水比が高いほど,同一の $\tau$ に対する $P_{m}$ の值は大きく, ほとんどの条件で $P_{m}$ は $\tau$ の 4 5 乗に比例している. この関係は, 掃流力が小さいときの砂粒の飛び出し率と せん断応力の関係に近い ${ }^{11)}$. 図中の*印は, $\tau>\tau_{c 2}$ での 結果である（ $\tau_{c 2}$ ：破壊限界. 著者らは底泥の流送に関 して 2 種類の限界掃流力を定義した. 1 つは流送限界 $\tau_{c 1}$ で底泥粒子の浮上が起こり始める限界時のせん断応 力 $\tau$ の值であり, 現象的には砂粒の移動限界に類似し ている. 他の 1 つは破壊限界 $\tau_{c 2}$ で底泥床面が破壊し大 量の底泥が短時間に流送される限界での $\tau$ の値であ

Table 1 Water content condition of clays and muds in hydraulic experiment.

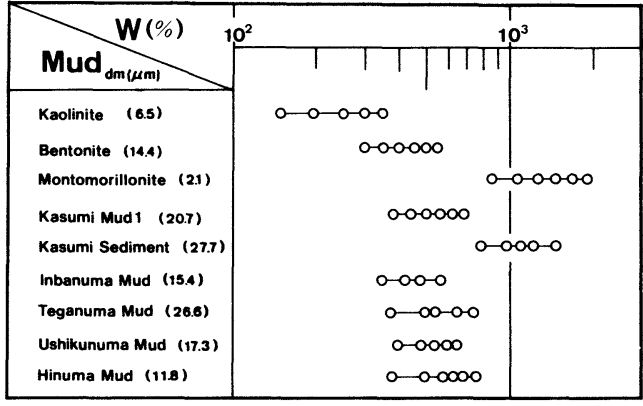
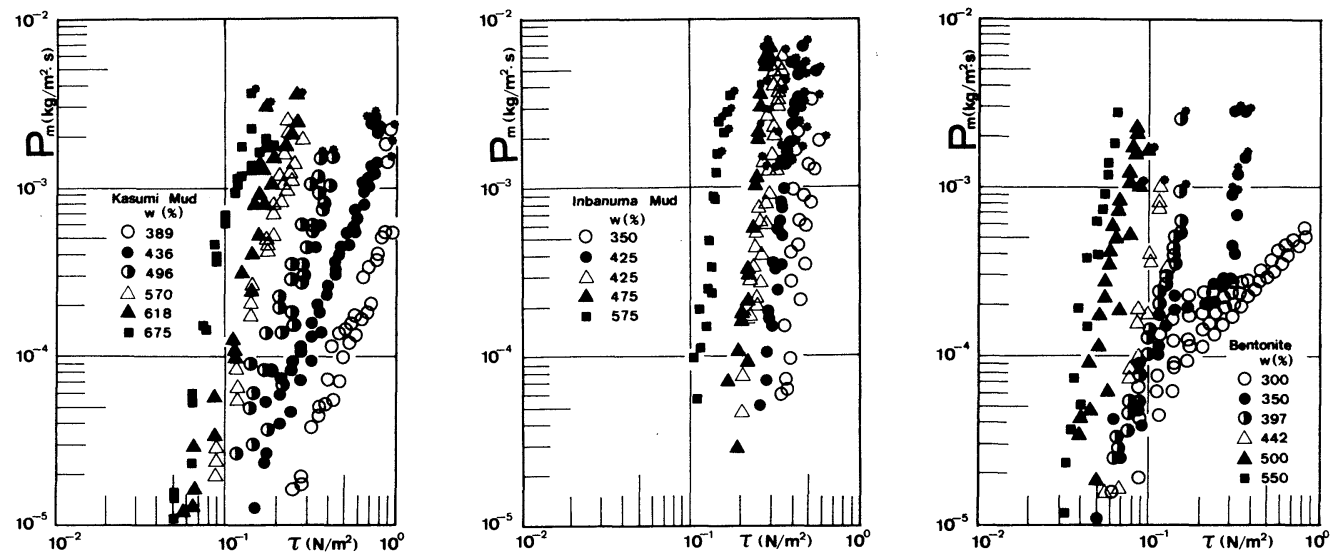

Fig. 1 Experimental results of resuspension mass $P_{m}$ and shear stress $\tau$. 
$\left.ろ^{1), 9)}\right) . \tau>\tau_{c 2}$ の状態では河床付近の流れが河床に沿わ なくなる，そのため河床は平坦床の場合より大きな流体 力を受けているため, *印のデータの $\tau$ の值は参考值 である. 低含水比では, 今回のせん断応力の範囲では破 壊が起こらないこともあった。

含水比 $w=300 \%$ および $350 \%$ のベントナイトでは, $P_{m} \propto \tau$ の関係が認められる.この場合の表面付近での 含水比は, 内側よりかなり高くなっていると推察され, 上層の流れと底面の間の不鮮明な境界面から一様に微細 粒子が連続的に浮上していた。

\section{(1) 連続体としての評価}

底泥を連続体とみて, 浮上現象を密度流界面での混合 現象ととらえる考え方がある．ただ底泥の場合には相対 密度 $\rho_{t} / \rho$ が 0.1 程度と大きく, 相対粘度 $\eta_{1} / \mu$ も 50 1000 と非常に高いのが通常の密度流界面とは異なる $\left(\rho_{t}\right.$ =底泥を連続体とみなした場合の見掛け密度; $\rho=$ 水の 密度 $; \eta_{1}=$ 底泥の粘度および $\mu=$ 水の粘度である). また， 同一密度でも底泥の種類により $\eta_{1}$ の值が異なり, 密度 差だけでは現象が規定できない，限界状態を内部波の砕 破と対応づけ，限界掃流力をクーリガン数で規定する研 究も行われた ${ }^{12)}$. Fig. 2 は, $u_{* c 2} /\left(\varepsilon \nu_{1} g\right)^{1 / 3}$ で定義したク一

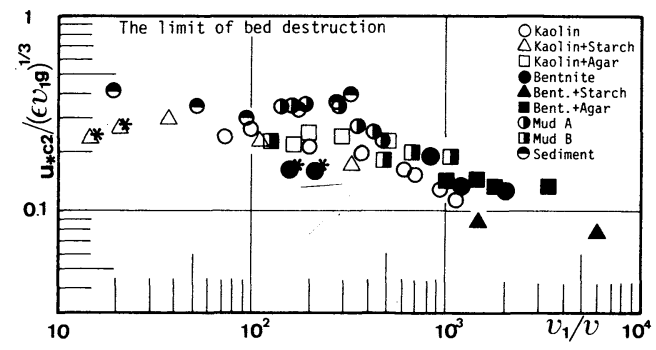

Fig. 2 Relation between Keulegan number $u_{* c 2} /\left(\varepsilon \nu_{1} g\right)^{1 / 3}$ and relative kinematic viscosity $\nu_{1} / \nu$.
リガン数 $K_{1}$ と $\nu_{1} / \nu$ との関係を示したものである ${ }^{13)}$.こ こで, $\varepsilon=\left(\rho_{t}-\rho\right) / \rho ; u_{* c 2}=\sqrt{\tau_{\mathrm{c} 2} / \rho}$ であり, $g$ は重力加 速度 $; \nu_{1}\left(=\eta_{1} / \rho_{t}\right), \nu$ はそれぞれ底泥および水の動粘性 係数である. Fig. 2 において*印の付いたデー夕が，内 部波らしきものが観察されたもので，粒径が小さくて分 散しやすい底泥において破壊限界值が $0.1 \mathrm{~N} / \mathrm{m}^{2}$ 程度の 条件で現われた， $K_{1}=$ const. で底泥の限界掃流力を規 定する試みがなされたが12)，Fig.2よりそれは難しいこ と，また内部波の現われる条件は $K_{1}$ の值によって決ま らないことがわかる.

Fig. 1 の飛び出し量の結果を連行係数表示した一例が Fig. 3 である. 連行係数 $E$ を $P_{m} /\left(u_{*} \rho_{t}\right)$ で定義した.こ こで $\rho_{t}$ は底泥を連続体とみた場合の見掛け密度， $u_{*}$ は 摩擦速度である. 横軸の $F_{i}^{2}$ はせん断応力 $\tau$ を代表値に とった内部フルード数の 2 乗值 $\tau /\left\{\left(\rho_{t}-\rho\right) g h_{u}\right\}$ である. ここで $h_{u}$ は上層水深で $5 \mathrm{~cm}$ である. $E$ と $F_{i}^{2}$ の関係 を $E \propto\left(F_{i}^{2}\right)^{\alpha_{1}}$ で表現すれば， $\alpha_{1}=4$ となり，通常の密度 流界面で得られている $\alpha_{1}=3 / 2$ に比べてかなり大きい. また比例定数も底泥の含水比によって異なっている.

横軸 $F_{i}^{\prime 2}$ を $\left(\tau-\tau_{c 1}\right) /\left\{\left(\rho_{t}-\rho\right) g h_{u}\right\}$ で定義して $E$ と $F_{i}^{\prime 2}$ の関係をみたのが Fig. 4 である. $E \propto\left(F_{i}^{\prime 2}\right)^{\alpha_{1}}$ で表現すれ ば, $\alpha_{1}=1 〜 2$ となるが, 比例定数はやはり含水比によっ て異なる.Fig. 5 は, 各底泥の粘度 $\eta_{1}$ が約 $0.3 \mathrm{~Pa} \cdot \mathrm{s}$ の ものを選んで， $E$ と $F_{i}^{\prime 2}$ の関係をみたものである．粘 度が同一でも，比例定数は底泥によって異なっている. 多くの実験条件の中で, 内部波が観察されたのはベント ナイトの 2 つ高含水比の場合だけで，河床の流動が観 察されたのはベントナイトのほかには高含水比 $\left(\eta_{1}<\right.$ $0.08 \mathrm{~Pa} \cdot \mathrm{s})$ の 3 条件のみであった. 内部波が現われな いことで即座に連続体的な取り扱いが不適当とは言及で きないが, 少なくとも通常の連行係数表示では底泥の飛 び出し量は規定できない，底泥の粘度や降伏值を含んだ

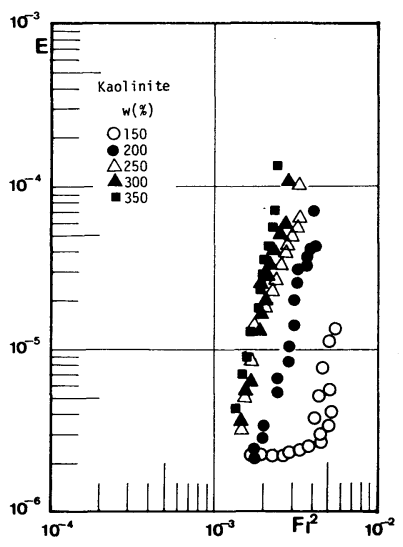

Fig. 3 Relation between $E$ and $F_{i}^{2}$.

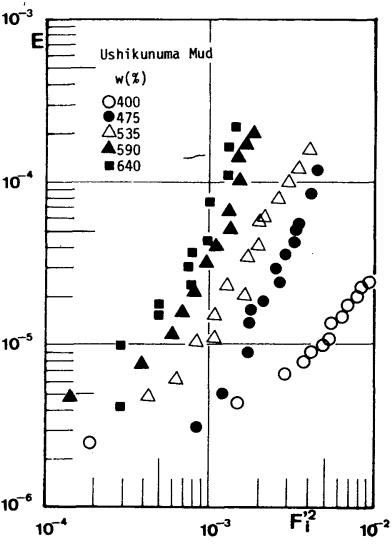

Fig. 4 Relation between $E$ and $F_{i}^{\prime 2}$.

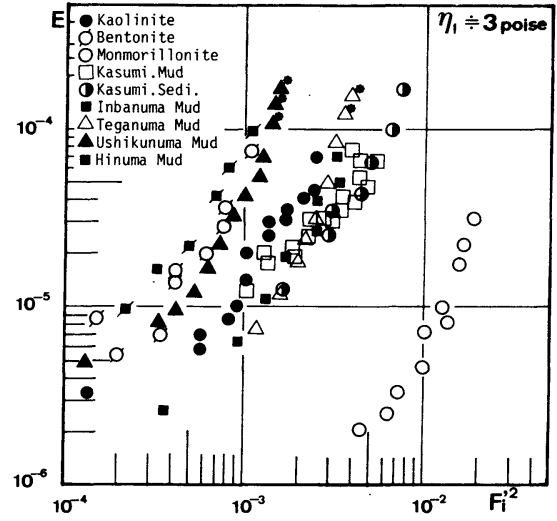

Fig. 5 Relation between $E$ and $F_{i}^{\prime 2}$ under almost the same viscosity condition. 
形に改良する必要があろう.

\section{（2）粒状体としての評価}

砂粒の場合，流送される量は流砂量として評価される ことが多い衴. 砂粒では step length が粒径の 100 倍程 度と非常に短いため, 流砂量は局所洗掘などの場合を除 いてその地点のせん断応力と結び付けられる. 一方, 底 泥ではstep length は非常に長く, 現地では平衡状態に 達しない可能性が高い。また, 湖沼や感潮河川部では, むしろ浮遊時間 (duration time) が必要となり, 平衡 状態量としての流泥量よりも飛び出し率や浮遊時間の評 価が重要となる。

非粘着性の砂粒に対する飛び出し率の推定式として は, 中川・辻本の式が知られている ${ }^{11)}$. 底泥についても 飛び出し率の無次元推定式を求めることが目的である. そのための第一段階として，次元解析的考察によって実 験結果の無次元表示を試みた。飛び出し量 $P_{m}$ の無次元 表示は，砂粒と同様に考えれば

$$
p_{m *}=\frac{A_{2}}{A_{3}} \frac{P_{m}}{\rho_{0} d_{0}} t_{0}=p_{m} t_{0}
$$

となる.ここで， $A_{2}$ および $A_{3}$ はそれぞれ粒子の面積お よび体積に関する形状係数， $\rho_{0}$ は飛び出し時の代表的 粒子の密度, $d_{0}$ はその粒径である. また $t_{0}$ は基準時間, $p_{m}$ は単位時間当たりに粒子が飛び出す確率で, 次元は $\left[T^{-1}\right]$ である。

砂粒の離脱の研究では, 基準時間として, Einstein や过本は「流れによらぬ特性時間」を，Paintel や早川 は「流れも含んだ砂粒の追従性を示す特性時間」を考え た ${ }^{15)}$. 底泥に対しては, 後者を採用して $t_{02}=$ $\left(d_{0} / u_{r}\right) \cdot\left(\eta_{1} / \mu\right)$ とし, 次に示す $p_{m *_{2}}$ なる無次元量を定義 した。ここで $u_{r}$ は粒子に作用する流れの代表流速であ る.

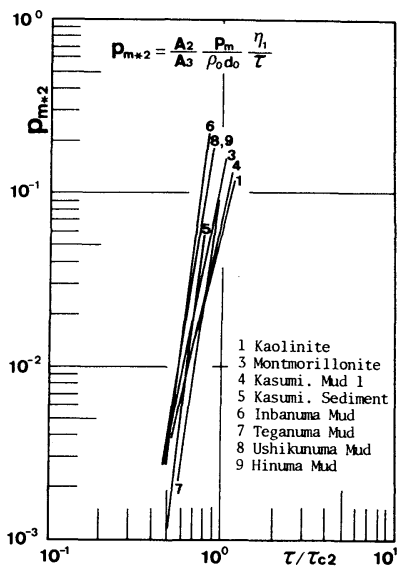

Fig. 6 Approximate dimensionless relation between mud resuspension rate and shear stress.

$$
p_{m * 2}=p_{m} t_{02}=\frac{A_{2}}{A_{3}} \cdot \frac{P_{m} \eta_{1}}{\rho_{0} d_{0} \tau}
$$

式（2）においては, 粒子径 $d_{0}$ が微細なため, $\tau$ と $u_{r}$ の間に $\tau \propto \mu\left(u_{r} / d_{0}\right)$ が成立するとし(粘性底層を想定), 比例定数は便宜的に 1 とした. 実験值 $P_{m}$ を式 (2) で 無次元化した， $\rho_{0}, d_{0}$ の值はそれぞれ次式で与えられ $ろ^{9}$.

$$
\begin{aligned}
& \rho_{0}=\frac{\rho_{\mathrm{t}}-\rho}{A_{3}}+\rho \ldots \ldots \ldots \ldots \ldots \\
& d_{0}=\left(\frac{100 \rho+w \sigma}{100 \rho}\right)^{1 / 3} A_{3}^{1 / 3} d_{m}
\end{aligned}
$$

ここで, $\rho$ は水の密度 $; w$ は含水比; $\sigma$ は底泥の真密度； $d_{m}$ は粒度試験で得られた底泥の平均粒径である。 せん 断応力の無次元表示としては後の 4. (2) で述べる理由 に基づいて限界掃流力 $\tau_{c}$ としては破壊限界 $\tau_{c 2}$ を採用 し, $\tau / \tau_{c 2}$ なる無次元量を考えた.

実験值における $p_{m *_{2}}$ と $\tau / \tau_{c 2}$ との間には, 同一底泥 においては含水比によらずほぼ一定の関係を得た。

Fig. 6 は第一グループの各底泥に対して得られた $p_{m * 2}$ と $\tau / \tau_{\mathrm{c} 2}$ の関係を両対数紙上で直線近似したものであ る. 多少のばらつきはあるが, 底泥によらず $p_{m * 2}$ と $\tau / \tau_{c 2}$ の関係は次式で整理される.

$$
p_{m * 2}=c_{2}\left(\frac{\tau}{\tau_{c 2}}\right)^{\alpha_{2}} \text {. }
$$

ここで $c_{2}$ および $\alpha_{2}$ は実験定数である．特性時間として $t_{02}$ を用いることにより, 底泥の飛び出し率の結果は含 水比や底泥の種類に関係なく一義的に整理された，基準 時間の考え方やせん断応力の無次元表示については他の 方法も検討したが，いずれの場合も Fig. 6 のようには整 理できなかった ${ }^{10), 16) .}$

\section{4. 底泥粒子の初期移動機構}

\section{（1）移動限界}

底泥の流送に対する抵抗力としては, 重力抵抗と粘着 抵抗が考えられる. 不飽和状態の土では表面張力の影響 がかなり大きいが底泥の場合は無視できよう.

粘着抵抗としては，降伏值によるものと粘度によるも のを取り上げた.本来これらは連続体的特性量であるが, 粘着力を微視レベルで評価できない現状では，これらが 粒子間の複雑な結合力を包括的に反映し, 粒子間個々の 粘着特性をも代表する量であると仮定して, 底泥の初期 移動現象を説明しようし試みた。降伏値によるものは現 象の時間スケールに無関係であり, 粘度によるものは応 力のかかる速度や変形速度などによって変化する. たと えば, 降伏值がなくて非常に高粘度の物質は, 応力が大 きくても作用時間が短ければ変形せず移動抵抗を発揮す るが，応力が小さくても長時間作用すれば変形はゆっく 
りではあるが進行する。一方，降伏值はもつが粘度が非 常に小さい物質の場合は, 作用時間が短くても応力が大 きいと破壊し，小さな応力ではそれが長時間作用しても 変形しない。粘度による破壊抵抗は延性強度に関係し, 降伏值によるそれは脆性強度に関係すると考えられる。

底泥の限界掃流力を評価する場合に粘度に起因する粘 着力を含めるか否かの問題がある. 応力の作用時間が短 ければこの力も初期移動抵抗に寄与するが, 流送現象で はせん断応力は常に底泥床面に作用しているので，この 粘着力は移動限界時の抵抗力としては寄与できないと考 えられる.そのため限界掃流力を評価するにあたっては, 粘度起因の粘着抵抗を考虑せず，静的なつり合い状態と して現象をとらえる必要がある.この粘着抵抗力は底泥 の運動に伴う力であって, むしろ底泥の飛び出し率を評 価する際に重要な因子となる.

\section{（2）限界掃流力に及ぼす重力の影䉕}

4.（1）に述べた主旨に沿って, 底泥の離脱に関する 限界状態を静的つり合い状態としてとらえる．この状態 でのつり合い式は

$$
\tau_{c}=\tau_{c g}+\tau_{y} \cdots
$$

となる.ここで $\tau_{c}$ は限界掃流力， $\tau_{c g}$ は重力に起因する 摩擦力, $\tau_{y}$ は移動粒子周辺の降伏値である。 $\tau_{\mathrm{cg}}$ は

$$
\tau_{c g}=k_{1}\left(\rho_{0}-\rho\right) g d_{0}
$$

で与えられる.ここで $k_{1}$ は比例定数， $\rho_{0}, d_{0}$ はそれぞ れ底泥粒子の代表密度と代表粒径である。 $\tau_{y}$ は

$$
\tau_{y}=k_{2} \tau_{y 1} \quad\left(k_{2}<1\right)
$$

と考えられる， $\tau_{y_{1}}$ は底泥の降伏值である ${ }^{10)}$. 底泥の限 界掃流力を評価するに際して, 重力に起因する抵抗力を 考慮する必要があるか否かを検討する. Table 2 は $\rho_{0}$ お よび $d_{0}$ の代表的な值に対して $\left(\rho_{0}-\rho\right) g d_{0}$ を求めたもの である. (1)では， $\rho_{0}$ および $d_{0}$ として物理試験 ${ }^{9}$ で求め た底泥の真比重と平均粒径を用いた. (2)および(3)では式

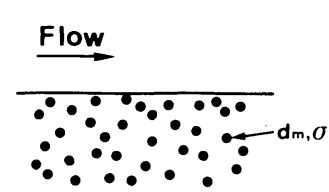

(a)
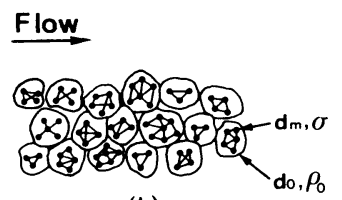

(b)
Fig. 7 Explanation sketch of density and diameter for resuspension sediment.

Table 2 Values of representative density $\rho_{0}$ and diameter $d_{0}$, 'and values of $\left.\left(\rho_{0}-\rho\right) g d_{0}\right)$.

\begin{tabular}{|c|c|c|c|c|}
\hline & $\begin{array}{c}\rho_{\circ} \\
\left(t / \mathrm{m}^{3}\right)\end{array}$ & $\begin{array}{c}d_{\circ} \\
(\mu \mathrm{m})\end{array}$ & $A_{3}$ & $\begin{array}{c}\left(\rho_{0}-\rho\right) \mathbf{g d}_{0} \\
\left(\mathrm{~N} / \mathrm{m}^{2}\right)\end{array}$ \\
\hline$(1)$ & $\sigma=2.3$ & $\mathrm{dm}_{2}=20$ & - & 0.255 \\
\hline$(2)$ & 1.2 & 38 & $\pi / 6$ & 0.074 \\
\hline (3) & 1.1 & 47 & 1 & 0.046 \\
\hline
\end{tabular}

（3）および式（4）で与えられる $\rho_{0}$ および $d_{0}$ を用い た. (2)は粒子を球状と仮定した場合, (3)は立方体と仮定 した場合である． $\rho_{0}$ および $d_{0}$ とも含水比によって多少 変化するが,ここでは平均的な值を用いた。. Table 2 に よれば含水比が高くて降伏值 $\tau_{y_{1}}$ が $0.1 \mathrm{~N} / \mathrm{m}^{2}$ 程度の場 合, $\tau_{c g}$ は $k_{1}$ の値によっては無視できないと考えられる. 非粘着性粒子の場合, 岩垣公式 ${ }^{14)}$ にれれば，砂粒レイノ ルズ数 $\operatorname{Re}_{*}\left(=u_{*_{c}} d_{m} / \nu\right)$ が 0.79 以下では $k_{1}=0.14$ で あり, Mantzの研究 ${ }^{17)}$ では, $0.03<\mathrm{Re}_{*}<1$ において $0.28>k_{1}>0.1$ である. 底泥粒子の場合, $k_{1}$ がどの程度 の值となるかは難しい問題である. 微視的には, 静止摩 擦係数を生み出す機構と粘着抵抗を生み出す機構は別の ものではなく，何らかのかかわりをもっており区別する のは困難である. しかし上記の $k_{1}$ の値は砂粒子が互い に直接接触している場合の值であり, 少なくとも Table 2 の(1)の条件には適用できないと考えられる. 高含水比 の場合, (1)の条件では底泥粒子は水中に分散して直接接 触していない。このとき(1)の条件は, 逆に $\tau_{c g}=0$ のモ デルとなる (Fig.7 (a) 参照). (2), (3)の条件は, モデ ル化の際に Fig.7 (b) のように粒子の接触を考えてい るので, $k_{1}$ の值としては 0.2 程度の值を考えてもよい. その場合， $\tau_{c g}$ は $0.01 \sim 0.015 \mathrm{~N} / \mathrm{m}^{2}$ となり， $\tau_{y 1}$ に比し て約 10 分の 1 となる. よって通常の堆積状態では， $\tau_{c g}$ は $\tau_{y_{1}}$ に比べて無視できる值と考えられる． $\tau_{c g}$ が無視 できるとなると，限界状態でのつり合い式は，

$$
\tau_{c}=\tau_{y}=k_{2} \tau_{y 1}
$$

となる, 降伏值 $\tau_{y}$ は, 底泥が流体として移動し始める 限界値であるので, 式 $(9)$ の $\tau_{c}$ は破壊限界 $\tau_{\mathrm{c} 2}$ に対 応するものと考えられる. 前報”における破壊限界に対 する実験結果も式（9）の成立を裏付けている． $k_{2}$ が 1 以下になる理由については前報1で考察した。

\section{（3）底泥の離脱様式}

底泥の限界掃流力を理論的に評価するに先立って, 底 泥での主要な離脱様式は何かを検討する．底泥の浮上・ 流送現象を粒状体的にみると,離脱の形態としては転動, 揚力による浮上，および滑動が考えられる．転動や揚力 による浮上離脱では底泥粒子は隣接する粒子から引き剝 がされ，滑動離脱では底泥粒子はずり剥がされる．その ため引き剥がしに要する力とずり剝がしに要する力を評 価して，その大小により主要な離脱様式を判定した。

粒子径 $d_{0}$ の粒子が隣接しその間隙を粘度 $\eta_{1}$ の物質が 埋めており, その結合部分は直径 $d_{*}$, 厚さ $h_{*}$ の円盤 と考える. 結合部分の中心を原点とし，水平方向に $r$, $\theta$ 軸を，鉛直方向に $z$ 軸を定義する．水平方向の粘着 物質の挙動は等方的とし, 簡単のため移動開始直後の状 態を考え，水中重量は無視する.

Fig. 8 （a）は引き剝がし過程の説明図である，最初， 


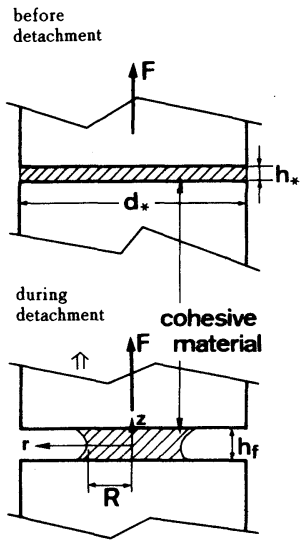

(a) tear-up separation before detachment

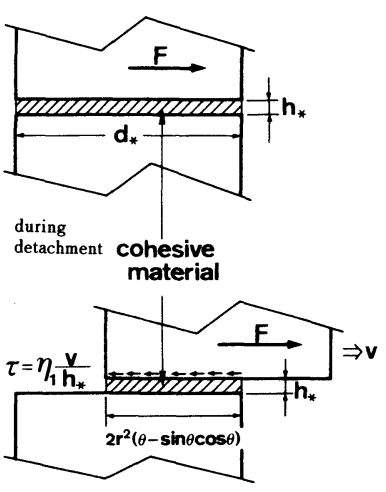

(b) tear-away separation

Fig. 8 Shematic figures of sediment's detachment styles.

2 個の粒子間の粘着物質は接触面積 $(4 / \pi) d_{*}^{2}$, 厚さ $h_{*}$ で存在しており，鉛直方向の力 $F に よ り$ 粒子間距離が 無限大となったとき引き剥がしが完了したと考える. $r$ $= \pm R, z=h_{f}$ の断面加単位時間に通過する粘着物質 の量は, 粘着物質の移動に伴う結合部分の単位時間当た りの変形量に等しいという関係と,引き剝がし過程では 粘着物質の体積 $V_{*}$ が一定であるということを考虑して 解析を進めると, 引き剝がしに要する力積は次式で与え られる ${ }^{18)}$.

$$
F t_{d}=-\frac{3}{8 \pi} \frac{V_{*}^{2}}{h_{*}^{4}} \eta_{1}=-\frac{3 \pi}{128} \frac{d_{*}^{4}}{h_{*}^{2}} \eta_{1}
$$

ここで $t_{d}$ は離脱時間である. Fig. 8 (b) は，ずり剝が し過程の説明図である.ずれが水平方向のみに起こり， せん断応力はずり剝がし過程中一定と仮定する. 結合部 の接触面積がゼロになったときずり剝がしが終了したと 考えると，ずり剝がしに必要な力積は次式で与えられ $ろ^{18)}$.

$$
\bar{F} t_{d}=\int_{0}^{t_{d}} F^{\prime} d t=\frac{1}{3} \frac{d_{*}^{3}}{h_{*}} \eta_{1}
$$

ここで $F^{\prime}$ は粒子に作用するずり㔀がし力 $\bar{F}$ は $F^{\prime}$ の $t_{d}$ 時間の平均値である.

式 (10), 式 (11) はいずれも限界時の静的つり合い 状態を示したものではなく，動き始めてから離脱するま でに必要な力積を示したものであるが，両式ともその力 積が離脱に要する時間に無関係となった.さてここでは, $t_{d}$ 時間で粒子が離脱するのに必要な力の大小によって, 引き剥がしとずり剝がしによる離脱とで，どちらが起こ りやすいかを判定する． $F$ と $\bar{F}$ の大きさの比を $F *$ と すると, $F_{*}$ は次式となる.

$$
F_{*}=\frac{|F|}{|\bar{F}|}=\frac{9 \pi}{128} \frac{1}{a_{*}}
$$

ここで $a_{*}=h_{*} / d_{*}$ である. Fig. 9 は $F_{*}$ と $a_{*}$ の関係

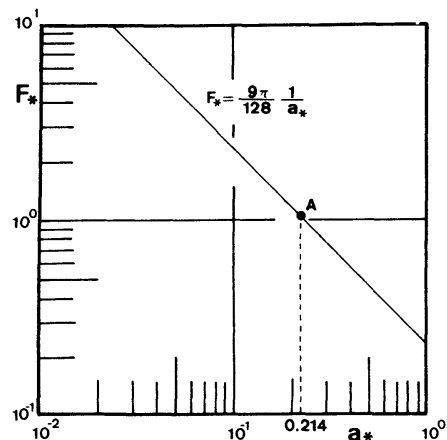

Fig. 9 Dependence of $F_{*}$ on $a_{*}$

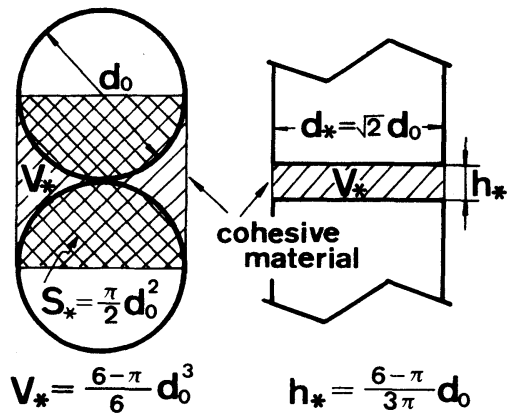

Fig. 10 Definition sketch

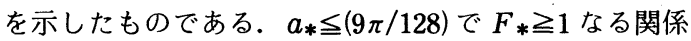
があり， $F_{*}$ は $a_{*}$ に反比例して大きくなる．いま，粒 子の充填型式として， $a_{*}$ が最大となる球粒子の単純立 方充填を考える (Fig. 10 参照). 粒子の直径を $d_{0}$ とす ると上下の粒子間の間隙体積 $V *$ は $(6-\pi) d_{0}^{3} / 6$ となる. 一方, 上下の粒子が相対している面積 $S_{*}$ は $(\pi / 2) d_{0}^{2}$ で ある. 換算結合部厚さ $h_{*}$ を $V_{*} / S_{*}$ で，換算結合部の 直径 $d_{*}$ を $(4 / \pi) S_{*}^{1 / 2}$ で定義すれば, $h_{*}=(6-\pi) d_{0} / 3 \pi$, $d_{*}=\sqrt{2} d_{0}$ となる. これらの $h_{*}, d_{*}$ の值を式 (12) に 代入すれば,

$$
F_{*}=\frac{9 \pi}{128} \cdot \frac{3 \sqrt{2} \pi}{6-\pi} \doteqdot 1.03 \text {. }
$$

となり, Fig.9ではA点で示される. 式（13）より， $a_{*}$ が最大と考えられる充填方式においても，ずり剥が しによる離脱のほうがやや力が少なくてすむことがわか る.一般に, 粘着力が支配力となっている状態では, $d_{*} \gg h_{*}$ が成立しており底泥の場合も例外でない，以上 の考察により, 底泥の離脱様式は力の少なくてすむ滑動 離脱（ずり㚸がれ）が主要となり, 転動や揚力による浮 上離脱 (引き永がれ) は補足的なものであると判断した。 観察結果でもこのことは確認された。河床から離脱した 後は, 粒子は滑動, 跳躍・浮遊など種々の形態で流下す るのが観察された。 


\section{5. 飛び出し率に関する理論的考察}

\section{（1）底泥粒子の運動方程式}

Fig. 6 より粘度 $\eta_{1}$ が飛び出し率 $p_{m}$ を支配する重要な 因子であることがわかる．粘度は物質が流動したときに 関与する物性であることを考えると, Fig. 6 の結果は底 泥の飛び出し率を評価するにあたって, 底泥粒子が静的 な力の均衡が破れたとき瞬間的に動くという解析では不 適当であり，粒子の離脱が時間のかかる現象とみて運動 方程式に基づく評価が必要なことを示唆する. 中川・辻 本は, 砂粒子に対する飛び出し率の推定式を, 粒子の回 転に関する運動方程式に基づいて求めている ${ }^{11)}$. 砂粒の 初期移動機構を転動離脱としてとらえ, 回転に関する運 動方程式から砂粒が転動離脱に要する時間 $t_{d}$ を評価し た.さらに，砂粒を移動させ得る流体力の持続時間 $p_{0} t_{0}$ を考え，その時間内に離脱する個数を $p_{0} t_{0} / t_{d}$ で 定義し，飛び出し率 $p_{s}$ を推定した。ここで $p_{0}$ はせん 断応力に変動を考え $\tau>\tau_{c}$ なる確率であり， $t_{0}$ は対象 とする砂の初期移動を考える際の変動をとらえる時間単 位である.

底泥に対しても，底泥を何らかの形状・大きさをもっ た粒子の集合体としてとらえるならば，砂粒と同様の考 え方が適用できる．相違点は，(1)底泥では抵抗力が重力 でなく粘着力であること，(2)高粘性のため慣性が無視で き移動直後に平衡速度に達すると考えられること, (3) 4. (3) で示した理由により初期移動形態が転動離脱で はなく滑動離脱であることである.

さて, Fig. 11 に示される状態の粒子 A が流れから力 を受け，河床面に沿って滑動で離脱するものとする．粒 子 $\mathrm{A}$ には，抗力 $D$ と粘性抵抗力 $R_{V}$ が作用すると考え， 揚力と水中重量による抵抗力は無視する．粒子 A の流 れ方向の運動方程式は次式で与えられるとする。

$$
\begin{aligned}
& A_{3}\left(1+C_{M}\right)\left(\rho_{0}-\rho\right) d_{0}^{3} \frac{d v}{d t}-k_{3} A_{1} \mu\left(u_{d}-u_{c}\right) d_{0} \\
& +k_{4} A_{1} \eta v d_{0}=0
\end{aligned}
$$

ここで， $A_{3}$ は体積に関する形状係数; $A_{1}$ は抗力および 粘性抵抗力に関する形状係数; $C_{M}$ は付加質量係数; $d_{0}$, $\rho_{0}$ は離脱時の底泥の代表粒径および密度 $; k_{3}$ および $k$, は比例定数; $v$ は粒子速度; $u_{d}$ は粒子近傍の流れの速度 ; $u_{c}$ は限界流速 $; \eta, \mu$ はそれぞれ底泥および水の粘度で ある. 左辺第 1 項は慣性項, 第 2 項は抗力項, 第 3 項は 粘性抵抗力項である. 式（14）を整理すると,

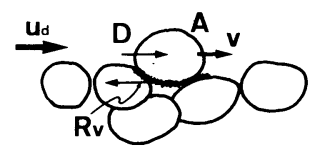

Fig. 11 Definition sketch.

$$
\begin{aligned}
& \frac{d v}{d t}+k_{4} A_{0} \eta v=k_{3} A_{0} \mu\left(u_{d}-u_{c}\right) \\
& A_{0}=\frac{A_{1}}{A_{3}}\left\{\left(1+C_{M}\right)\left(\rho_{0}-\rho\right) d_{0}^{2}\right\}^{-1} .
\end{aligned}
$$

となる.これを解くと，

$$
\frac{v}{v_{0}}=1-\exp \left(-k_{4} A_{0} \eta t\right)
$$

が得られる.ここで $v_{0}$ は

$$
v_{0}=\frac{k_{3}}{k_{4}} \frac{\mu}{\eta}\left(u_{d}-u_{c}\right)
$$

で与えられる平衡速度である． $k_{3}$ および $k_{4}$ の正確な值 は不明であるが, 流体力と粘性抵抗力が粒子の上下半分 ずつに作用すると仮定して， $k_{3}=k_{4}=1 / 2$ とする.

\section{（2）底泥粒子の移動速度}

初期移動のモデル化において, 粒子の移動速度が平衡 速度 $v_{0}$ で近似できるか否かを検討する．粒子が粒径分 移動するのに要する時間 $T_{d}$ に比べて,$v / v_{0}=0.9$ にな る時間 $t_{p}$ が十分小さければ， $v=v_{0}=$ const. とみなし てよいであろう. 式 $(17) よ り, ~ v / v_{0}$ は $A_{0}$ および $\eta$ の值によって変化し, 両数值が小さいほど $v / v_{0}=0.9$ となる時刻 $t_{p}$ は大きくなる。 そこで $\eta$ の值は，流送実 験における $\eta_{1}$ の下限値に近い $0.1 \mathrm{~Pa} \cdot \mathrm{s}$ とした. $A_{0}$ の 值は底泥粒子を球形と仮定し， $\rho_{0}$ および $d_{0}$ として Table 2 と対応させて 2 つの条件について式 (16) より 求めた. Table 3 に 2 つの組合せに対する $A_{0}, t_{\rho}, T_{d}$ の值および $T_{d} / t_{p}$ の值を示した ${ }^{9}$. 2 つの条件とも $T_{d} / t_{p} \gg 1$ となり, 底泥粒子の初期移動のモデル化に際 しては, 粒子は移動開始直後から平衡速度 $v_{0}$ で移動す ると考えてよいことが明らかとなった。

\section{（3）無次元飛び出し率の定式化}

底泥は式（18）で表わされる平衡速度で河床から離脱 するが，流体力は乱れによって変動している，底泥は高 周波の変動に対しては応答せず，ある程度持続した力に のみ応答する．初期移動に関与する流体力変動を砂粒の 場合と同様に取り扱う。 $t_{d}$ を底泥粒子が離脱するのに 要する時間とすると, $p_{0} \hat{t}_{0} / t_{d}$ は $p_{0} \hat{t}_{0}$ 時間（粒子を離 脱させ得る流体力の持続時間）内に飛び出す底泥粒子の 個数となるので, 単位時間当たりの離脱粒子個数を全体 の時間にわたって考えると, 飛び出し率 $p_{m}$ は次式で定 義される。

$$
p_{m}=\frac{p_{0} \hat{t}_{0}}{t_{d}} \frac{1}{\hat{t}_{0}}=\frac{p_{0}}{t_{d}}
$$

Table 3 Values of $t_{p}, T_{d}$ and $T_{d} / t_{p}$

\begin{tabular}{|c|c|c|c|c|c|c|}
\hline & $\begin{array}{c}\rho_{\mathrm{o}} \\
\left(\mathrm{g} / \mathrm{cm}^{3}\right)\end{array}$ & $\begin{array}{c}\mathrm{d}_{\mathrm{o}} \\
(\mu \mathrm{m})\end{array}$ & $\begin{array}{c}\mathrm{A}_{0} \times 10^{3} \\
(\mathrm{~cm} / \mathrm{g})\end{array}$ & $\begin{array}{c}\mathrm{t}_{\mathrm{p}} \times 10^{-3} \\
(\mathrm{~s})\end{array}$ & $\begin{array}{c}\mathrm{T}_{\mathrm{d}} \times 10^{-3} \\
(\mathrm{~s})\end{array}$ & $\mathrm{T}_{\mathrm{d}} / \mathrm{t}_{\mathrm{p}}$ \\
\hline$(\mathrm{a})$ & 1.2 & 38 & 4115 & 0.001 & 6.33 & 6330 \\
\hline$(\mathrm{b})$ & 2.3 & 20 & 2308 & 0.002 & 2.34 & 1670 \\
\hline
\end{tabular}




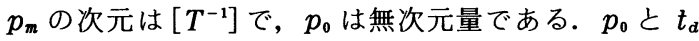
を評価できれば， $p_{m}$ が推定できる．底面せん断応力の 分布を中川・辻本と同様に正規分布と仮定し, その確率 密度関数を $f(\tau)$ とすれば $p_{0}$ は次式で与えられる.

$$
p_{0}=\left\{\int_{\tau_{c}}^{\infty} f(\tau) d \tau\right\} /\left\{\int_{0}^{\infty} f(\tau) d \tau\right\}
$$

次に底泥の離脱時間 $t_{d}$ について考える．底泥の移動 に伴う粒子の接触面積の減少は無視し，離脱する間の底 泥粒子の粘度や移動速度の変化も考えない. 底泥の離脱 を底泥が $a_{1} d_{0}$ だけ移動した状態と定義すると， $t_{d}$ は次 式で与えられる.

$$
t_{d}=\frac{a_{1} d_{0}}{v_{0}}=\frac{a_{1} \eta}{\left(u_{d}-u_{c}\right) \mu} .
$$

ここで $a_{1}$ は定数である. 底泥表面は水理学的滑面で9), 粘性底層内で次の関係が成立しているとする.

$$
\begin{aligned}
& u_{d}=\frac{\rho u_{*}^{2}}{\mu} a_{2} d_{0}=a_{2} d_{0} \frac{\tau}{\mu} \cdots \\
& u_{c}=\frac{\rho u_{* c}^{2}}{\mu} a_{2} d_{0}=a_{2} d_{0} \frac{\tau_{c}}{\mu} .
\end{aligned}
$$

ここで， $a_{2}$ は定数で $a_{2} d_{0}$ は局所流速 $u_{d}$ の作用高さを 示す. 式 (22), 式 (23) を式 (21) に代入し, さらに 底面せん断応力の変動を考慮すると $t_{d}$ は次式のように 変形される.

$$
t_{d}=\frac{a_{1}}{a_{2}} \eta \frac{1}{E\left[\tau \mid \tau>\tau_{c}\right]-\tau_{c}}
$$

$E\left[\tau \mid \tau>\tau_{c}\right]$ は持続時間 $p_{0} \hat{t}_{0}$ の間に作用する条件付平 均底面せん断応力である. なお式 (24) は底泥表面を粗 面と考えても導かれる．その場合には，式（14）の左辺 第 2 項の抗力を $\left(u_{d}^{2}-u_{c}^{2}\right)$ に比例するとし,$u / u_{*}$ の関係 式としては粗面対数則を適用する.

底面せん断応力の分布特性を考慮して解析を進める
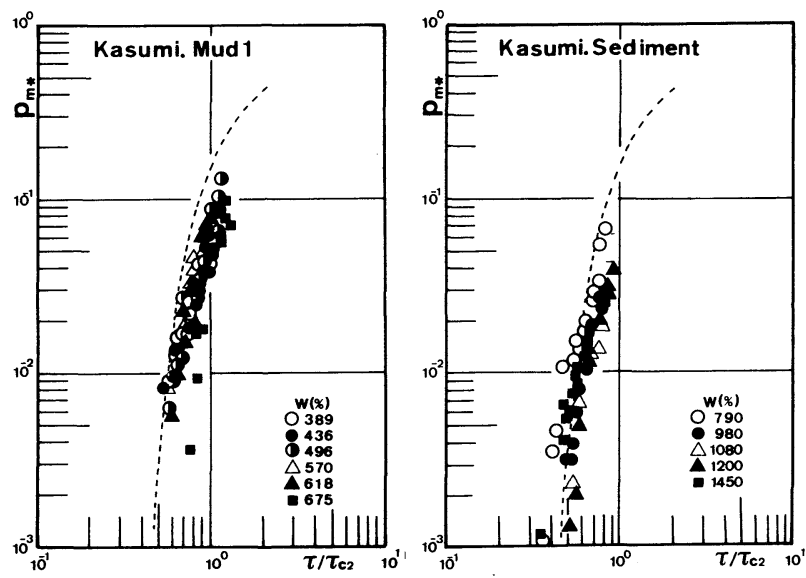

Fig. 12 Relation between $p_{m *}$ and $\tau / \tau_{c 2}$ (Experimental' results and theoretical curve).
と， $t_{d}$ は結局次式で与えられる ${ }^{9), 11)}$.

$$
t_{d}=\frac{a_{1}}{a_{2}} \frac{\eta}{\bar{\tau}}\left\{1+\delta_{0} \frac{\Phi\left(y_{c}\right)}{p_{0}}-\frac{\tau_{c}}{\bar{\tau}}\right\}^{-1}
$$

ここで $\bar{\tau}$ はせん断応力 $\tau$ の平均値; $\sigma_{1}$ はその標準偏差; $\delta_{0}$ は変動係数; $\Phi(y)$ は誤差関数; $y_{c}=\left(\tau_{c}-\bar{\tau}\right) / \sigma_{1}$ であ る. よって, 無次元飛び出し率 $p_{m *}$ は式 $(20)$ と式 $(25)$ より次式で与えられる.

$$
p_{m *}=\frac{\eta}{\tau} p_{m}=\frac{a_{2}}{a_{1}}\left\{1+\delta_{0} \frac{\Phi\left(y_{c}\right)}{p_{0}}-\frac{\tau_{c}}{\tau}\right\} p_{0}
$$

式 (26) では改めて $\tau=\bar{\tau}$ と置いた. Fig. 12 における破 線は, 式 $(26)$ より求めた $p_{m *}$ と $\tau / \tau_{c}$ との関係である. その際，底泥粒子が粒径分移動したときを離脱と考えて $a_{1}=1$ とし， $a_{2}$ には 0.75 を，また $\delta_{0}$ には砂粒と同様に 0.5 を用いた ${ }^{11), 19)}$. 水理学的滑面での底面せん断応力や 圧力変動の結果からすると, 今回の底面せん断応力に関 する仮定でも問題はないと考えられる201 23).

理論曲線は $\tau / \tau_{c}<1$ では急勾配で， $\tau$ が増加するとと もに勾配は急激に減少してゆく. $\tau / \tau_{c} \gg 1$ では式 $(26)$ で $\left\{1+\delta_{0}\left(\Phi / p_{0}\right)-\left(\tau_{c} / \tau\right)\right\} p_{0} \rightarrow 1$ となり $p_{m *} \rightarrow\left(a_{2} / a_{1}\right)=$ 0.75 となる.このモデルでは, 河床が破壊しなければ(実 際には破壊してしまうが $), \tau / \tau_{c} \gg 1$ の場合でも $\tau / \tau_{c}<$ 1 の場合と同じ現象が起こることを想定している.

\section{（4）無次元飛び出し率の推定式と実験結果との比較}

式 (26) の誘導の過程では限界掃流力 $\tau_{c}$ の值につい て言及しなかった。現象的には $\tau_{c}$ は流送限界 $\tau_{c 1}$ に対 応するように思われるが，4.（2）に展開した議論から すれば $\tau_{c}$ としては $\tau_{c 2}$ を用いるのが妥当と思われる. せん断応力の変動を考慮したことにより, 平均底面せん 断応力が限界掃流力以下でも, 底泥粒子の飛び出しは定 義可能となった. Fig. 12 は霞ケ浦泥 1 と霞浦沈降物 における $p_{m *}$ と $\tau / \tau_{c 2}$ の関係で, 理論曲線と実験値 $(\eta$ $=\eta_{1}$ として整理）との整合性がよい，他の底 泥についても同様な結果が得られた9). $\tau_{c}=\tau_{c 2}$ とした $p_{m *}$ の理論曲線は物理的に意味あいま いなパラメーターを導入することなく, 底泥の 飛び出し率の推定曲線として利用できると考え られる.また Fig. 12 の結果は Fig. 6 の実験的 事実の合理的説明にもなっている.

底泥の無次元飛び出し率の推定式の特徵は, 砂粒の場合には $p_{s *}$ が $\tau / \tau_{c}>1\left(\tau_{c} / s g d=\right.$ 0.035 と考える. ここで $s=\rho_{s}-\rho ; \rho_{s}=$ 砂の密 度 ; $d$ =砂粒径である. ) の範囲で定義されるの に対して, 底泥の場合には $p_{m *}$ は $\tau / \tau_{c}<1$ の 範囲で定義されることである. すなわち，底泥 が全体としては流動化しておらず，底泥粒子に 破壊限界を越える流体力が離脱時間より長く作 用したとき，その粒子が飛び出すという状況を 
想定している. 常に $\tau>\tau_{c 2}$ の状態では, 底泥は表層の みならず下層も流動することになり, 河床が破壊される. そうなると流れも河床に平行に作用しなくなり局所的な 付加せん断応力が大きくなって, ここで展開した移動機 構とは全く異なったものになる.このような状態には式 （26）を適用することはできない.

このモデルは, 降伏値をもつ第一グループの底泥のみ に適用できるものであり, 降伏值のない第二グループの 底泥には適用できない，さらに含水比が低すぎても適用 できない. 低含水比の（降伏値 $\tau_{y 1}$ が大きい）場合には, 底泥層内部は全く流動しないのにもかかわらず，底泥表 層から微細粒子がわずかに巻き上がる現象が観察され た.これは, 界面付近のごく薄い層で含水比が高く（降 伏值が小さく）なっているため, 薄層内の底泥粒子が飛 び出したものと考えられる.この現象は $\tau_{y 1}>2 \mathrm{~N} / \mathrm{m}^{2}$ の 実験で観察された。この場合には底泥表層部に内部と異 なった含水比を考慮した解析が必要となる. 以上より式

（26）が適用できるのは, 第一グループに属する底泥で, $\tau_{y 1}$ が $0.1 \sim 2 \mathrm{~N} / \mathrm{m}^{2}$ となる含水比の場合に限定される. しかし, 湖沼や感湖河川部等に堆積している底泥のほと んビが第一グループに属し, さらに現地における底泥の 表層部は上記の含水比条件を満足していると考えられる ことから ${ }^{24)}$, 式 (26) の適用範囲はかなり広いと考えら れる.

\section{（5）無次元飛び出し率による流送限界の再評価}

流送限界 $\tau_{c 1}$ は力学的つり合い条件で決められる静的 なものではなく, 底泥の飛び出し量が無視できるせん断 応力の上限值で定義される現象論的なものであると考え られる. 前報では, $P_{m}=3 \times 10^{-5} \mathrm{~kg} / \mathrm{m}^{2} \mathrm{~s}$ を流送限界の 判定基準とした.この場合流送限界 $\tau_{c 1}$ と降伏值 $\tau_{y 1}$ に は $\tau_{c 1}=0.35 \tau_{y 1}^{0.59}$ の実験的関係が得られたが, 両者の次 元は合わなかっだ1).ここでは $p_{m *}=$ const. $\left(=3 \times 10^{-3}\right)$ で流送限界を評価する方法を提唱する. 式 (26) を用い てこの $p_{m *}$ に対する $\tau / \tau_{c 2}$ の值を求めると 0.5 となり, 流送限界 $\tau_{c 1}$ と破壊限界 $\tau_{c 2}$ には $\tau_{c 1} / \tau_{c 2}=0.5$ の関係が 成立することになる. さらに式 $(9)$ より $\tau_{c 1}=0.5 k_{2} \tau_{y 1}$ となり, 降伏值 $\tau_{y 1}$ とも結び付くのですっきりとした定 義となる.

\section{6. 結 論}

本論文では, 飛び出し率を中心に底泥の初期移動機構 を実験的・理論的に論じた. 得られた成果を要約すると 以下のようである.

（1）飛び出し量の連続体的な取り扱いと粒状体的取 り扱いの良否を検討した. その結果, 底泥の飛び出し量 に関しては, 後者の取り扱いが適当であることを示し, 式（5）で示される無次元実験式を得た.
（2）底泥の流送に対する抵抗力としては粘着力が支 配的で重力抵抗が無視できること，また移動に関する限 界状態を考えるにあたっては降伏値のみが抵抗力として 問題となるが, 浮上量を評価する際には降伏値のほかに 粘度に起因する抵抗力も重要になることを明らかにし た.

（3）底泥粒子の主要な離脱様式を離脱に要する運動 量の大きさから検討し，それが滑動離脱であることを明 らかにした。

（4）底泥粒子の離脱過程において粘度に比例する粘 性抵抗が作用するとして, 粒子の滑動に関する運動方程 式を導いた。 そして, 底泥の粘度が高いため移動粒子は ただちに平衡速度に達すると考えて, 底泥粒子の離脱に 要する時間を評価した。さうに，流体力の変動を正規分 布と仮定し，初期移動に支配的な乱れの周期に基づく流 体力の作用持続時間を考えて, 無次元飛び出し率の推定 式を導いた。

（5）推定式は定数值の決定などに検討の余地が残さ れてはいるが，底泥の種類や含水比の影響を包括し，実 験結果とも良好に一致した。このモデルで第一底泥グ ループに属する底泥の初期移動現象を十分記述し得るも のと考えられる. 飛び出し時の底泥粒子の代表的密度 $\rho_{0}$ および代表的粒径 $d_{0}$ の決定も今後に残された課題で ある．これらの量は粒子の水中での挙動を考察する場合 にも重要となる. 霞ケ浦沈降物の離脱・浮上後の粒子の 平均粒径 $d_{m}^{\prime}$ が粒度試験で求めた平均粒径 $d_{m}$ の $1 \sim 2$ 倍 程度であったこと ${ }^{9)}$, Matsuo \& Kamon の研究 ${ }^{25)} ゙ も$ 自 然堆積状態のへドロのペッドの単位が $10 〜 20 \mu \mathrm{m}$ であ り, 定方向径の比が 1 前後という結果を得ていることか ら, 式 (3) および式 (4) による $\rho_{0}, d_{0}$ の評価はあ ながち不適当ではないと思われる.

（6）推定式をもとに新しい流送限界の定義を提案し た.それは, 無次元飛び出し率の一定值（著者は $p_{m *}=$ $3 \times 10^{-3}$ を提案する）を限界の判定基準とするものであ り，この方法によれば, 流送限界も値こそ異なるが, 降 伏値 $\tau_{y 1}$ に比例することになり, 理論的にも明解で客観 性もあると考えられる。

\section{参 考 文 献}

1）大坪国順・村岡浩爾：底泥の物性及び限界掃流力に関す る実験的研究，土木学会論文報告集，第 363 号, pp. 225 $\sim 234,1985$.

2) 村岡浩爾：流れによる底泥浮上と水質との関連，第 18 回 土木学会水理講演会論文集, pp. 181 186, 1974.

3) Partheniades, E. : Erosion and deposition of cohesive soils, Proc. A. S. C.E., 91, HY 1, pp. 105 139, 1965.

4）楠田哲也・海田輝之・栗谷陽一・石原達弘：底泥の巻き 上げと沈降に関する基礎的研究（II），第 18 回土木学会 
衛生工学研究討論会論文集, pp. 152 158, 1982.

5）澤井健二：粘着性流路床の変動機構に関する土砂・水理 学的研究, 京都大学学位論文, 1977.

6) Einstein, H.A. : Formula for the transportationn of bed load, Trans. A. S. C. E., Paper No. 2140, pp. 561 597, 1942.

7）細井由彦：底泥浮上モデルに関する一考察, 土木学会第 36 回年次学術講演会講演概要集第 II 部, pp. 1 2, 1981.

8) Einstein, H. A. and Li, H. : The viscous sublayer along a smooth boundary, Proc. A.S.C.E., EM-2, pp.1 $27,1956$.

9）大坪国順：底泥の物性及び流送特性に関する実験的研究, 国立公害研究所研究報告, 第 42 号, 1983.

10）大坪国順・村岡浩爾：底泥の飛び出し量に関する研究, 第 26 回土木学会水理講演会論文集, pp. $141 \sim 146$, 1982.

11）中川博次・辻本哲郎：水流による砂碟の移動機構に関す る基礎的研究, 土木学会論文報告集, 第 244 号, pp. 71 $\sim 80,1975$.

12）細井由彦・住友 恒・岩井重久：底泥の捲きあげに関す る実験的研究 (II ), 第 15 回土木学会衛生工学研究討論 会論文集, pp. 28 33, 1979.

13）大坪国順・村岡浩爾 : 底泥の物性と限界掃流力の関連に ついて, 第 25 回水理講演会論文集, pp. 73 78, 1981,

14）たとえば，土木学会編：水理公式集，土木学会，1985.

15）辻本哲郎：掃流過程の確率モデルとその移動床問題への 応用, 京都大学学位論文, 1978 .

16）大坪国順・村岡浩爾：底泥の飛び出し率の推定, 第 28 回 土木学会水理講演会論文集, pp. 671 677, 1984.

17) Mants, P.A. : Incipient transport of fine grains and flakes by fluids-Extended Shields Diagram-, Proc. A. S. C. E. , 113, HY 6, pp. $601 \sim 615,1977$.

18) Otsubo, K, and Muraoka, K. : Resuspension rate function rate for cohesive sediments, Jour. of Hydroscience and Hydraulic Eng., J.S.C.E., Vol. 3, No.2, pp.1 13, 1985.

19) Einstein, H.A. and El-Sami, E.A. : Hydrodynamic forces on a rough wall, Review of Modern Physics, 21, pp. 520 524, 1949.

20) Willmarth, W.W. and Wooldridge, C.E. : Measurements of the fluctuating pressure at the wall beneath a thick turbulent boundary layer, J. Fluid Mech., Vol. 14, pp. $187 \sim 210,1962$.

21) Corcos, G. M. : The structure of turbulent pressure field in boundary layer flows, J.Fluid Mech., Vol.18, pp. 353 378, 1964.

22) Grass, G. M. : Structual features of turbulent flow over smooth and rough boundaries, J. Fluid Mech., Vol.50, pp. 233 260, 1971.

23) Blinco, P.H. and Simons, D. B. : Characteristics of turbulent boundary shear stress, Proc. A. S.C.E., April, EM 2, pp. 203 220, 1974.

24）大坪国順・村岡浩爾：霞ケ浦底泥の物性および堆積特性 に関する調查と検討, 第 21 回衛生工学研究論文集, pp. 201 210, 1985.

25) Matsuo, S. and Kamon, M. : Microscopic study on deformation and strength characteristics of clay soil, Proc. 9 th. Int. Conf. SM. \& F.E., 1, pp. 201 204, 1977.

(1985.6.27 • 受付) 